\title{
Commentary: Postrepair mitral stenosis: A pyrrhic victory
}

\author{
Stacey Chen, MD, and Eugene A. Grossi, MD
}

One more such victory and we are undone. ${ }^{1}$

- Pyrrhus of Epirus

The concept of a pyrrhic victory can be traced back to King Pyrrhus of Epirus, and his victory over the Romans in the Battle of Asculum in $279 \mathrm{BC} .^{1}$ Although victorious in battle, Pyrrhus sustained such heavy losses that his conquest was ultimately futile, forcing him to end his campaign against the Roman Empire.

El-Eshmawi and colleagues ${ }^{2}$ report their experience with patients who underwent mitral valve reoperation for symptomatic moderate to severe postrepair mitral stenosis (MS). ${ }^{2}$ A total of 35 patients were included in the analysis with 22 undergoing mitral valve replacement and 13 undergoing mitral valve re-repair. At the index mitral valve repair (MVr) operation, the median annuloplasty ring used was $28 \mathrm{~mm}$ with quadrangular leaflet resection and commissuroplasty or edge-to-edge repair being the second most common repair techniques applied. The median time from initial MVr to reoperation was 4.5 years. At the time of reoperation, the authors reported that the most common etiologies of MS were pannus ingrowth $(57 \%)$ and leaflet calcification $(34 \%)$. There were no in-hospital or 1-year mortalities and survival at 5-year follow-up was $93.9 \%$.

El-Eshmawi and colleagues ${ }^{2}$ are to be commended for their excellent outcomes in the operative management of these patients, but there is a cautionary tale here. Postrepair MS is a consequence of orifice narrowing after $\mathrm{MVr}$ and its incidence is associated with either the use of a small,

From the Department of Cardiothoracic Surgery, NYU Langone Health, New York, NY.

Disclosures: The authors reported no conflicts of interest.

The Journal policy requires editors and reviewers to disclose conflicts of interest and to decline handling or reviewing manuscripts for which they may have a conflict of interest. The editors and reviewers of this article have no conflicts of interest.

Received for publication Dec 17, 2020; revisions received Dec 17, 2020; accepted for publication Dec 18, 2020.

Address for reprints: Eugene A. Grossi, MD, Department of Cardiothoracic Surgery, NYU Langone Health, 530 First Ave, Suite 9V, New York, NY 10016 (E-mail: eugene.grossi@nyulangone.org).

J Thorac Cardiovasc Surg 2023;165:e150-1

$0022-5223 / \$ 36.00$

Copyright $₫ 2020$ Published by Elsevier Inc. on behalf of The American Association for Thoracic Surgery

https://doi.org/10.1016/j.jtcvs.2020.12.079

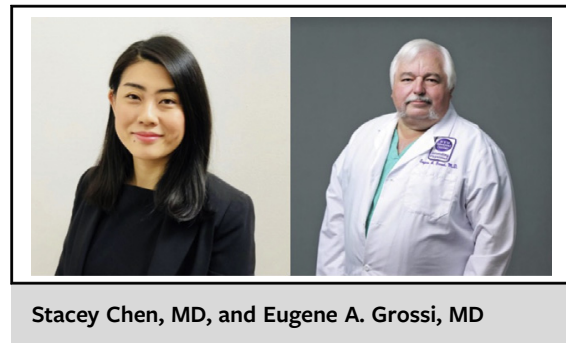

CENTRAL MESSAGE

Postrepair mitral stenosis chal-

lenges the durability of mitral

valve repair. Strategic surgical

techniques should be imple-

mented during the initial

intervention to mitigate this

complication.

undersized annuloplasty ring or a complete ring with the criteria of functional MS being met in nearly half of an at-risk degenerative population 5 years after repair. ${ }^{3}$ In a recent study, Kim and colleagues ${ }^{4}$ reported their experience with the long-term clinical sequelae of patients who developed functional MS following MVr. They demonstrated that patients with functional MS had an increased incidence of new-onset atrial fibrillation and tricuspid regurgitation, required more reoperations, and had decreased long-term survival. Data from both these studies illustrate that the durability and success of a mitral repair cannot simply rely on the absence of residual mitral regurgitation. Moreover, it is important to highlight that the management of postrepair MS is challenging. Although mitral re-repair is feasible in select patients, the authors report that 2 rerepair patients required mitral valve replacement for recurrent MS $<2$ years after their re-repair operations. ${ }^{2}$ As our understanding of postrepair MS continues to evolve with emerging mid- and long-term data, among the most important lessons we can learn from the experience reported by El-Eshmawi and colleagues ${ }^{2}$ is that we must remain prudent in our surgical techniques for initial MVr to mitigate postrepair MS. Lest we forget the story of Pyrrhus.

\section{References}

1. Plutarch. Plutarch's Lives: Volume I. J. Dryden, translator. New York, NY: Modern Library; 2001.

2. El-Eshmawi A, Sun E, Boateng P, Pandis D, Rimsukcharoenchai C, Anyanwu A, et al. Lessons from reoperations from mitral stenosis after mitral valve repair. J Thorac Cardiovasc Surg. 2021;161:937-46. 
3. Mesana TG, Lam BK, Chan V, Chen K, Ruel M, Chan K. Clinical evaluation of functional mitral stenosis after mitral valve repair for degenerative disease: potential affect on surgical strategy. J Thorac Cardiovasc Surg. 2013;146:1418-25.
4. Kim JH, Lee SH, Joo HC, Youn YN, Yoo KJ, Chang BC, et al. Long-term clinical impacts of functional mitral stenosis after mitral valve repair. Ann Thorac Surg. September 24, 2020 [Epub ahead of print]. 